УДК 378:165

\title{
ОСОБИСТІСНО-ОРІЕНТОВАНИЙ ПІДХІД ДО ВИХОВАННЯ У ПЕДАГОГІЧНИХ ІДЕЯХ В. СУХОМЛИНСЬКОГО
}

\author{
В. Й. Кульчицький \\ ДВНЗ “Тернопільський держсавниймедичний університет імені I. Я. Горбачевського МОЗ Украйни”
PERSONAL-ORIENTED APPROACH TO THE TRAINING IN PEDAGOGICAL IDEAS OF V. SUKHOMLYNSKY \\ V. Y. Kulchytskyi \\ SHEI "Ternopil State Medical University by I. Ya. Horbachevsky of MPH of Ukraine"
}

\begin{abstract}
У статті розглянуто проблему особистісно-орієнтованого підходу до виховання у педагогічних ідеях В. Сухомлинського, проаналізовано значення особистісно-орієнтованої освіти у становленні особистості, зосереджено увагу на основних принципах особистісно-орієнтованого підходу до навчання та виховання особистості.
\end{abstract}

The article deals the problem of a personal-oriented approach to educational ideas of V. Sukhomlynsky, the value of personaloriented education in the development of personality was analyzed, focus on the basic principles of personal-oriented approach to the individual training and education.

Вступ. Процес розбудови сучасної української освіти, що здійснюється відповідно до вимог Закону України "Про освіту", Державної національної програми “Освіта (Україна ХХІ століття)”, неможливий без урахування існуючого вітчизняного та зарубіжного педагогічного досвіду.

У сучасних умовах державотворення в Україні зростає роль гуманістичного виховання підростаючого покоління. У Законі України “Про освіту” метою освіти визначено всебічний розвиток людини як особистості та найвищої цінності суспільства, розвиток її талантів, розумових і фізичних здібностей, виховання високих моральних якостей, формування громадян, здатних до свідомого суспільного вибору, збагачення на цій основі інтелектуального, творчого, культурного потенціалу народу. Велика роль у цьому процесі належить педагогам, які повинні формувати особистість відповідно до вимог сьогодення.

Одним із найефективніших підходів до реформування сучасної освіти названо особистісно-орієнтований підхід. Так, у Державній національній програмі “Освіта (Україна XXI століття)" наголошується, що навчально-виховний процес повинен здійснюватись на національному грунті, в “органічному поєднанні 3 національною історією і народними традиціями”. Умови сьогодення висувають суспільний запит на виховання творчої особистості, здатної самостійно мислити, пропонувати оригінальні ідеї, приймати

(c) В. Й. Кульчицький сміливі, нестандартні рішення. Тому орієнтиром змісту освіти та виховання є розвиток особистості у максимально можливому діапазоні росту ії індивідуальних ресурсів. Це зумовлює потребу переосмислення історико-педагогічного досвіду в історії української педагогіки.

У науковий період становлення особистісно-орієнтованої освіти та виховання великого значення набувають погляди відомого українського педагога В. Сухомлинського. Його творчість увійшла до історії вітчизняної педагогічної думки помітною сторінкою, його педагогічні, публіцистичні та літературні праці й учительський досвід значно вплинули на практичну діяльність школи, збагатили педагогіку України новими положеннями і думками. Педагогічна спадщина В. Сухомлинського багатопланова. Вона зазнавала певної еволюції, постійно збагачувалася, поглиблювалася. Його педагогічна концепція високогуманна і демократична, органічно поєднує класичну і народну педагогіку. У працях класика української педагогіки містяться всі або майже всі положення, що можуть бути покладені в основі сучасної концепції особистісно-орієнтованого навчання й виховання.

Педагогічна спадщина В. Сухомлинського глибоко вивчається в Україні, Росії, багатьох країнах світу. Ідеї В. Сухомлинського набули широкого розголосу далеко за межами України. Науково-педагогічний та практичний доробок В. Сухомлинського постійно привертає увагу вітчизняних та зарубіжних науковців й освітян - М. Антонця, Р. Атаяна, А. Борисовсько- 
го, М. Богуславського, М. Вашуленка, Г. Волокова, С. Заволоки, М. Мухіна, А. Розенберга, О. Сухомлинської, В. Смаля та ін. Аналіз останніх наукових досліджень 3 приводу особистісно-орієнтованого підходу свідчить, що в даному аспекті існує кілька напрямків: розкриття “парадигмальної формули” сучасного гуманістичного підходу (І. Зязюн, С. Подмазін, А. Маслоу); визначення засобів особистісноорієнтованого навчання і виховання учнів та студентів (I. Бех, О. Бондаревсько, В. Свдокімова, О. Падалко, О. Савченко, О. Пєхота та ін.); формування творчої особистості (В. Андрєєва, Д. Богоявленська, Н. Гузій, В. Кан-Калік, Н. Кічук, В. Моляко) [1].

Метою нашого наукового дослідження $є$ необхідність аналізу педагогічних ідей В. Сухомлинського як основи особистісно-орієнтованого підходу до виховання.

Основна частина. Одним iз найефективніших підходів до реформування сучасної освіти, відповідно до Національної доктрини розвитку освіти, президент АПН України, академік НАН України В. Кремень назвав особистісно-орієнтований підхід [3].

Проте робота щодо розробки теорії і методики особистісно-орієнтованої освіти поки ще далека від завершення і в першу чергу це стосується ії концептуальної основи. Фундамент уже $є$, але деякі із принципових положень, запропонованих авторами сучасних розробок, суперечливі, а деякі - другорядні. 3 огляду на це звертає на себе увагу відсутність глибокого і всебічного аналізу спадщини класиків української педагогіки XX століття, які велику увагу приділяли питанням упровадження індивідуального підходу до навчання і виховання особистості.

Так, одним із основних положень у системі поглядів В. Сухомлинського на сутність навчально-виховного процесу є положення про неповторність кожної молодої людини. Положення про неповторність кожної дитини є немовби наріжним каменем, на якому побудована вся система поглядів українського педагога на проблеми навчання й виховання. Таке ж важливе значення воно має і для концепції особистісно-орієнтованого підходу, оскільки саме з нього випливає положення про дитину як найвищу цінність і, відповідно, головного суб' єкта навчально-виховного процесу.

Поняття “особистісно-орієнтований підхід” у працях В. Сухомлинського відсутнє. Не формулювалися ним ні принципи, ні методи особистісно-орієнтованого підходу. Проте більшість його праць тією чи іншою мірою присвячена питанням особистісного, індивідуального підходу до молодої людини і, по суті, вирішує проблеми ії розвитку.
Індивідуалізація навчально-виховного процесу - це навчання і виховання кожного учня за індивідуальним планом. "Досвід переконує, - пише В. Сухомлинський у статті “Народний учитель”, - якщо в школі, скажімо, шістсот учнів, то це означає, треба шукати шістсот індивідуальних стежок" [4].

Розкриваючи суть індивідуального, диференційованого підходу до навчання й виховання, В. Сухомлинський постійно використовує поняття “особистість дитини”. В його працях можна зустріти словосполучення “колектив і особистість", “людська особистість", “підростаюча особистість”, “всебічно розвинена особистість" та ін.

Сьогодні у педагогічній науці яскраво заявляє про себе особистісно-орієнтований підхід, який забезпечує створення нових механізмів навчання і виховання та грунтується на принципах глибокої поваги до особистості, самостійності особи, врахування індивідуальності. “Особистісно-зорієнтоване виховання це утвердження людини як найвищої цінності, навколо якої грунтуються всі інші суспільні пріоритети", вважає I. Бех [1]. Сутність особистісно-зорієнтованого виховання полягає в тому, щоб розбудити інтерес дитини до власної особистості, до саморозвитку за допомогою самоціннісної діяльності.

На думку В. Сухомлинського, ідея людяності насамперед реалізується через розвиток всіх потенціальних, інтелектуальних і фізіологічних можливостей особистості. Всебічно розвинена особистість втілює в собі повноту і гармонію сил, здібностей, пристрастей, потреб, які визначають моральну, ідейну, громадянську, розумову, творчу, трудову, естетичну, емоційну, фізичну досконалість.

Важливим аспектом особистісно-орієнтованого виховання є реалізація принципів педагогіки співробітництва. Погляди В. Сухомлинського на роль колективу і місце в ньому особистості сьогодні не менш сучасні й злободенні, ніж вони були під час написання ним праць 3 цього питання, адже співробітництво між молодими людьми найяскравіше проявляється у колективі. "Колективізм, - пише він у праці 'Проблеми виховання всебічно розвиненої особистості”, - не тільки результат виховання, а й процес, і комплекс засобів, які формують свідомість, погляди, переконання, вчинки людини. Життя і праця в колективі $\epsilon$ школою становлення буквально всіх рис особистості... Від того, які ідеї лежать в основі трудових, духовних, морально-естетичних взаємовідносин між членами колективу як людської спілки, залежить становлення понять і уявлень особистості про добро і зло, про обов' язок і справедливість, честь і гідність" 
[6]. Одна з найважливіших потреб людини - радість спілкування, емоційно-чуттєва насиченість відносин між людьми, яка має велике значення і для навчання та виховання особистості.

Особистісно-орієнтований підхід має суттєво гуманізувати навчально-виховний процес, наповнити його високими морально-духовними переживаннями, утвердити принципи справедливості і поваги, максимально розкрити потенційні можливості дитини, стимулювати ії до особистісно-розвивальної творчості.

Здатність до розвитку - важлива властивість особистості протягом всього життя людини. Процес виховання (самовиховання) - центральне поняття педагогіки, а може, і всього життя людини.

Визначальним компонентом виховної системи $\epsilon$ педагогічно обгрунтована мета. Виходячи зі сформульованих ідей, принципів, змісту виховання, мета особистісно-зорієнтованої системи-особистість, яка може побудувати життя, що варте людини.

У зв'язку з цим, виховна система покликана дати молоді якомога більше знань про суспільство, озброїти ії системою соціальних навичок, умінням адаптуватися до змінних соціально-економічних умов, тобто сформувати “компонентну особистість", яка здатна не тільки сприймати умови реального життя, але й перетворювати їх.

Педагогічна спадщина В. Сухомлинського - особистісно-зорієнтована, оскільки зосереджується на вирішенні індивідуальних проблем, які виникають у процесі соціалізації конкретної людини, засобами вивчення іï особистості та довкілля, складання індивідуальної програми допомоги; сприяє дітям і молоді зорієнтуватися у вирі суспільних подій та явищ, в оволодінні соціальним досвідом, самостійному пошукові професійного і життєвого шляху [2].

Теоретичні узагальнення великого педагога містять положення, які можуть розглядатися як принципи особистісно-орієнтованого підходу до навчання та виховання і можуть бути покладені у його фундамент. Вони мають деякі схожі риси з положеннями, які лежать в основі сучасної концепції особистісно-орієнтованого підходу, але значною мірою відрізняються від них, що свідчить про невикористані можливості педагогічної спадщини В. Сухомлинського у розробці теорії і методики означеного підходу: принцип неповторності кожної дитини; принципурахування нерівності розумових здібностей дітей; принцип урахування нерівності розумових здібностей дітей; принцип індивідуалізації навчально-виховного процесу; принцип врахування індивідуальних особливостей учнів; принцип визнання кожного учня особистістю; принцип отри- мання позитивних почуттів від навчання; принцип навчання через подолання труднощів; принцип дослідницького підходу до предмета вивчення; принцип обов'язковості самостійної розумової праці учнів у процесів навчання; принцип людяності, чуйності і тактовності по відношенню доучнів; принцип розуміння оцінки знань учнів як інструмента виховання; принцип взаємозалежності колективу і особистості у навчанні; принцип залежності особистості учня від особистості вчителя.

Таким чином, головною метою навчально-виховного процесу В. Сухомлинський вважав всебічний розвиток особистості [4]. На його думку, зміст виховання насамперед спрямований на задоволення внутрішніх потреб людини, тобто потреб ії буття, особистісного існування: свободи і вільного вибору свого світогляду, дій, вчинків, позицій, самостійності і самореалізації, самовизначення, творчості тощо [5].

Виховання - це педагогічне управління процесом розвитку особистості. Особистісно-зорієнтоване виховання основане на гуманістичних засадах, має характер діалогу. Тому у роботі педагога пріоритет надається непрямому педагогічному впливу, коли на першому плані - діагностичні засоби спілкування, спільні пошуки істини, розвиток за допомогою спеціально створених виховних ситуацій, різноманітна творча діяльність.

Зміст особистісно-зорієнтованого виховання повинен включати все, що потрібно людині для формування своєї особистості, тобто те, що допомагає їй продукувати власне життя. Щоб знайти себе, індивіду потрібно вибрати і вибудувати власний світ цінностей, увійти у світ знань, оволодіти творчими способами розв'язання наукових і життєвих проблем, відкрити світ власного “Я” і навчитися керувати ним.

Сучасна система освіти, яка використовує особистісно-орієнтовані технології, має на меті досягнення особливого психологічного клімату, в умовах якого дитина почувалася б комфортно. Основні засоби ті самі, що і в “Школі радості" В. Сухомлинського: неформальне спілкування педагога з учнями не тільки в позаурочний час, а й під час уроків; переважання позитивних оцінок, іноді повна відмова від оцінок; увага до позаурочного життя (походи та екскурсії, театр, гуртки); головний критерій у роботі педагогів - терпіння та любов до дітей; дружні стосунки між дітьми в класі, які не залежать від навчальних, успіхів тощо [6].

В. Сухомлинський вважав, що виховувати - означає залучати до гуманістичних за своєю суттю цінностей діяльності переживання і взаємозв'язків. Сди- 